areas with the Upper Bonlder-clay of the Lancashire plain, but was not certain that they were of Hessle age. The solution of the main question depended chiefly on the relative age of the Wolverhampton and Stafford clay-and-gravel, which be was disposed to regard as the equivalent of the lower brown Boulder-clay of the N.W. and likewise of the chalky clay of Lincolnshire. He concluded by considering facts which might be regarded as opposed to this view, and by giving his reasons for regarding the palæontological evidence of the relative age of deposits as not, in all cases, reliable.

\title{
CORRESPONDENOE.
}

\section{RECENT MOLLUSCA ON THE SIBERIAN TUNDRA.}

Sir,--On the 14th January, 1878, Mr. Henry Seebohm read a paper before the Royal Geographical Society, on his visit to the valley of the Yenesei in 1877 , and which was subsequently published in the Proceedings of the same Society. In his most interesting account of that region, the tundras are thus described. "The Siberian 'tundra' is something like the fjelds of Lappland, something like a Scotch moor or an Irish bog. It is a wild undulating extent of country, full of rivers, lakes, and swamps, stony, but not rocky, gay with brilliant will flowers, abounding with ground fruits, such as crowberry, cranberry, clondberry, and Arctic strawberry, and swarming with clouds of mosquitoes. The hill tops are barren and stony, but the valleys shelter dwarf willows and stunted birch.

"These 'tundras' are evident]y rising gradually. Ancient drift wood, roited into tinder, is often found above the present limit of the highest floods, and at Gol-cheek'-a (N. lat. $71^{\circ} 30^{\prime}$ on the Yenesei), I found large heaps of recent sea-shells at least four miles from the river-bank, and 500 feet above the level of the sea."

Mr. Seebohm kindly permitted me to examine the specimens which he gathered from the position referred to, and with the aid of Mr. Edgar A. Smith, the following species were determined.

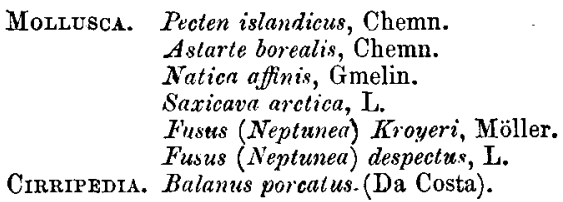

The recent elevation of the Siberian tundras is well known, and in the travels of M. de Middendorf and Von Wrangel frequent allusion is made to the subject. Mr. Henry H. Howorth, in a very -interesting paper, published in the Journal of the Royal Geographical Society of London, 1873, was brought together and discussed an immense amount of information in regard to the recent elevations of the earth's surface in the northern circumpolar region, in which the tundras of Siberia come in for due share of notice, and makes it unnecessary for me to do more than refer to his paper. 
The special interest of Mr. Seebohm's observation lies in the fact of the very great elevation, namely, 500 feet, at which he procured the specimens I have recorded, all of which are now existivg and common in the neighbouring seas. H. W. Feildex.

THE PENNINE CHAIN.

Sir,-Will you allow me to say a word on the subject of the geological age of the Pennine Chain? Some five or six years ago I became aware of the fact that the Coal-measures in the neighbourhood of Nottingham have a fairly persistent north and south strike beneath the Permian rocks, and that some of the north and south faults in the Coal-measures do not affect the overlying rocks, at any rate to anything like the same extent. I immediately saw that these facts were sufficient to prove that the Carboniferous rocks had been subjected to a north and south series of disturbances before Permian times; and I concluded that since the Pennine axis follows the same direction it probably belongs to the same period. I mention this not for the purpose of claiming priority over my friend $\mathrm{Mr}$. Wilson in this matter, but merely for the purpose of justifying my interference in the present discussion.

Now, Sir, I contend that the evidence of pre-Permian flexuring and faulting along north and south lines in this neighbourhood is quite sufficient to settle the question as to the date of the origin of the first movements in this direction.

I think both Mr. Wilson and Prof. Hull, in discussing this question, are a little hampered by the notion of anticlinal axes forming barriers. Thus, the greater portion of Prof. Hull's letter (Geol. MaG. Vol. VI. p. 573) is devoted to a consideration of the question of the similarity of deposits on opposite sides of the Pennine Chain, and this of course is strictly relevant to the discussion as raised by Mr. Wilson (Grou. MAG. Vol. VI. p. 500). It does not, however, affect the question of the date of the north and south movements, which is really the important question at issue. On this question, all the direct evidence I know of points to the conclusion that these disturbances originated during the immense interval of time which elapsed between the close of the Carboniferous period and the commencement of that portion of the Permian period which is represented by deposits forming the eastern boundary of the exposed portion of the Nottingham and Yorkshire Coal-basin.

I have read Prof. Hull's paper on this question, Q.J.G.S. vol. xxiv. p. 382, and, like Mr. Wilson, I fail to see that the evidence there alduced, in favour of the Post-Permian and Pre-Triassic date of the origin of these north and south disturbances, is of much value, even when standing by itself, and I consider that it is completely destroyed by the fact, mentioned above, that the Coal-measures strike north and south beneath the Permian rocks for some distance north of Nottingham. Prof. Hull seems to think that the physical discordance here referred to is slight, and supposes it to be due "to a sort of sympathetic movement which took place during the progress of the more powerful east and west flexuring at the close 